\title{
The Application of International Internal Audit Standards by Licensed Commercial Banks in Sri Lanka
}

\author{
I.A.N.S. Madurasinghe ${ }^{1} \&$ W.D.N.S.M. Tennakoon ${ }^{2}$ \\ ${ }^{1}$ Commercial Bank of Ceylon PLC \\ Colombo 02 \\ SRI LANKA \\ ${ }^{2}$ Department of Business Management \\ Faculty of Business Studies \& Finance \\ Wayamba University of Sri Lanka \\ Kuliyapitiya \\ SRI LANKA \\ Nadeera_Madurasinghe@ combank.net ${ }^{1}, \underline{\text { tennakoon@wyb.ac.lk }}$
}

\begin{abstract}
Compliance with the International Internal Audit Standards (IIASs) is obligatory to ensure the credibility of the audit reports. In Sri Lankan context, the extent of IIASs application by the financial institutions is still unclear as no formal investigation has been performed so far to address the same. Thus, the purpose of the present study was to assess the application of IIASs by the commercial banks of Sri Lanka. A quantitative research was carried out to reach the research objective. A field survey of population aided in deriving the empirical evidences. Unit of analysis was Licensed Commercial Banks (LCBs) in Sri Lanka. Closed-ended, self-administrated questionnaire was distributed among the internal auditors of LCBs. Opinions of respondents were solicited using a five-point Likert scale ranging from 1 to 5 . Regression model was used to analyse data with the support of SPSS statistical package. Results suggested a moderate level application of IIASs by LCBs. However, the extent of IIASs application found significantly vary among three categories of IIASs. The attribute standards seemed the heavily applied IIASs category by Sri Lankan LCBs compared to performance standards and implementation standards. The least level of application was evidenced with respect to performance standards. Theoretically, findings appear significant as there is a short of research work carried out in internal auditing, particularly on IIASs in the global context as well as in Asian context. As managerial implications of this research, it can be noted that LCBs should pay much attention in raising the application of IIASs where performance standards principally need much attention relative to other two standards.
\end{abstract}

Keywords: Licensed Commercial Banks in Sri Lanka (LCBs), Institute of Internal Auditors (IIAs), International Internal Auditing Standards (IIASs), Attribute Standards, Performance Standards, Implementation Standards 


\section{INTRODUCTION}

Banks play a central role in the economy through their liquidity and credit creation function (Calema and Michael, 2004). So that the commercial banks do. Further, banking industry is highly regulated in any country. To be in compliance with the set regulations by rule setters and to achieve bank's objectives in an effective and efficient manner, banks should have a better internal control system to prevent inconsistencies. Internal controls can be defined as the policies and procedures employed by executives of an institution to realise their set objectives (Makgatho, 2016). Hence, internal controls determine the achievement of bank's objectives in an effective manner with respect to operations, reporting and compliance (COSO, 2013).These internal controls may deviate from the expected due to different management styles, work force capabilities and changing internal \& external environments. As a result, it is necessary to conduct an internal control review and this review should involve in internal checks, an internal audit, the custody of assets, and accuracy of records (Makgatho, 2016). This review has to be ongoing or separate (COSO, 2013). As per Makgatho (2016) internal audit is one way of reviewing internal controls. It gives a reasonable assurance of existence of a proper internal control system (COSO, 2013). Having identified the major role of commercial banks in an economy, it is pertinent to identify the importance of maintaining an effective and efficient internal control system in a bank. Further, banks can create vulnerabilities of systematic nature, partly due to a mismatch in maturity of assets and liabilities and their inter connectedness. The soundness of banks is important, as it contributes towards maintaining confidence in the financial system, and any failure may have the potential to impact on activities of all other financial and non-financial entities, and finally the entire economy (CBSL, 2018). Further, auditing of banks efficiently is a requirement due to problems that banks could encounter in their financing function those may cause serious effects in the economy (Zengin \& Yu ksel, 2016). Internal auditing is an independent \& objective assurance and consulting activity designed to add value and to improve organization's operations. It helps an organization to accomplish its objectives by bringing a systematic, disciplined approach to evaluate and improve the effectiveness of risk management, control and governance process (IIA, 2015). In order to comply with above statement of IIASs, banks have to comply with mandatory guidance principles implemented by IIAs (IIA, 2015). Mandatory guidance consists with standards, code of ethics and core principals. Hence, banks should apply IIASs as partial compliance with IIASs rules in their internal audit function. The management of the organization is responsible for designing, implementing and maintaining internal controls appropriate for preparation and fair presentation of financial statements (Gunathilaka, 2012). Separate standards may be in action in different territories and countries depending on their legal system. However, as per IIAs (2015), IIASs are the standards 
published by International Professional Practice Framework (IPPF). In Sri Lanka, audit standards followed are "The Sri Lanka Accounting and Auditing Standards" issued under the Act No. 15 of 1995 (CA Sri Lanka, 2018). LBCs in Sri Lanka are also liable to adopt these evaluations in addition to Sri Lanka Auditing Standards (SLAuSs). The banking sector in Sri Lanka mainly comprises with Licensed Commercial Banks (LCBs) and Licensed Specialised banks (LSBs). LCBs dominate the financial system and account for the highest share of the total assets in the financial system. Banks play a critical role within the Sri Lankan financial system, as they engage in provision of liquidity to the entire economy, while transforming the risk characteristics of assets (CBSL, 2018). As per CBSL (2018), in terms of the asset base and the magnitude of services provided, the LCBs are the single most important category of financial institutions within the banking sector. LCBs dominate the financial system with the highest market share of the entire financial system's assets. Therefore, the health of Sri Lankan financial system depends to a large extent on the soundness of the LCBs, primarily on the performance and financial strength of the six largest LCBs. Hence, they are generally referred as the Systemically Important Banks (SIBs) of Sri Lanka. As such, it is utmost important to have the best method of control over LCBs both by the regulator and their own management. Internal controls should function as intended and they need periodical evaluations to ensure the adequacy and effectiveness.
The establishment of Accountancy board in 1941 and the Institute of Chartered Accountants of Sri Lanka in 1959 considered as catalyst to the auditing profession in Sri Lanka. The companies' Act No 7 of 2007 was introduced replacing the companies Act No 17 of 1982 and the Companies ordinance of 1938. Sri Lanka Accounting and Auditing standards Act No 15 of 1995 was developed by the Ministry of Finance and Planning with the assistance of the accounting professionals and representatives from the commercial and financial sector. Institute of Chartered Accountants of Sri Lanka formulates accounting and auditing standards in Sri Lanka under the Sri Lanka Accounting and Auditing standards Act No 15 of 1995. This Act was developed in response to the recommendations made by the Public Enterprise Reform Commission which was established in 1995. The Act established Sri Lanka Accounting and Auditing Standards monetary Board (SLAASMB). It established Statutory Accounting Standards Committee and the Auditing Standards Committee (AuSC). The AuSC promulgates SLAuSs in par with the International Standards on Auditing (ISAs) of International Auditing and Assurance Standards Board (IAASB) of International Federation of Accountants (IFAC) with slight modifications to meet local requirements. Accounting and auditing in corporate sector of Sri Lanka is directly subject to the international influence of IAASB, IFAC, International Monetary Fund (IMF), the World Bank (WB), and the Asian Development Bank (ADB) 
(Prem, Sarath, and Siriwardhane, 2017).

LCBs adapt SLAuSs issued under the Act No. 15 of 1995 (CA Sri Lanka, 2018). It was mentioned that the SLAuSs are based on the ISAs published by IAASB of the IFAC, with adjustments to match the local context. Hence, compliance with the SLAuSs ensures compliance in all material components of the international standards on auditing. Yet, in Sri Lanka, no formal administrative arm is monitoring the compliance of LCBs towards ISAs even though LCBs are expected to follow them in spite of their compliance to SLAuSs.

Further, a study in Sri Lanka has found that the internal audit department which is entrusted to perform the internal audit function is not efficient, is understaffed, doesn't conduct regular audit activities and doesn't produce regular audit reports. The study also found that there is lack of information sharing and inadequate security measures to safe guard the assets. The study established a significant relationship between internal control system and financial performance as well (Gamage, Lock, \& Fernando, 2014).

In light of these, a question arises as to whether international internal auditing standards published by IPPF are applied properly by Sri Lankan commercial banks.

Since internal audit has become a value creator for improving the effectiveness of risk management, control and governance systems (Dellai \& Omri, 2016), researches aimed at internal auditing have significantly increased over the recent past (Metlib \& Turki , 2017). Many scholars have studied several aspects of internal auditing with wider focus on efficiency, relevance, globalization and organizational features. However, only a few scientific studies have studied the internal audit standards and their application (Turaev, 2017). In particular, research works have been carried out to ascertain the level, and the effective application of SLAuSs with a greater focus towards the financial statements in Sri Lankan context. Yet, there had been no research study to assess the application of IIASs to the best knowledge of the researchers. Application of IIASs in Sri Lanka seems to be an area untapped so far by researchers in the field of finance. Further, when it is concerned about approaching the global markets by Sri Lankan companies, it is obvious that they have to adhere to global standards. Banking industry is not an exception. LCBs too have to comply with the requirements and subsequently to globally accepted accounting and auditing standards. In other words, LCBs have to comply with IIASs in global dealings. In addressing the absence of any study assessing the, the present study focused on finding the level of IIASs application by Sri Lankan LCBs.

The main three categories of International Internal Auditing standards (IIASs) are:

1. Attribute Standards

2. Performance Standards

3. Implementation Standards of IIASs serve as the bases for the 
research questions of the study. There are,

1. Does application of attribute standards predict the application of IIASs by Sri Lankan LBCs

2. Does application of performance standards predict the application of IIASs by Sri Lankan LBCs

3. Does application of implementation standards predict the application of IIASs by Sri Lankan LBCs

Accordingly, the main objective of the study was to assess the extent of IIASs application by Sri Lankan LCBs specific objectives of the assessing the application level of three main categories of IIASs namely, attribute standards, performance standards, and implementation standards. The conceptual model of the study depicted the assumed connection $\mathrm{s}$ between key variables (Figure 1).

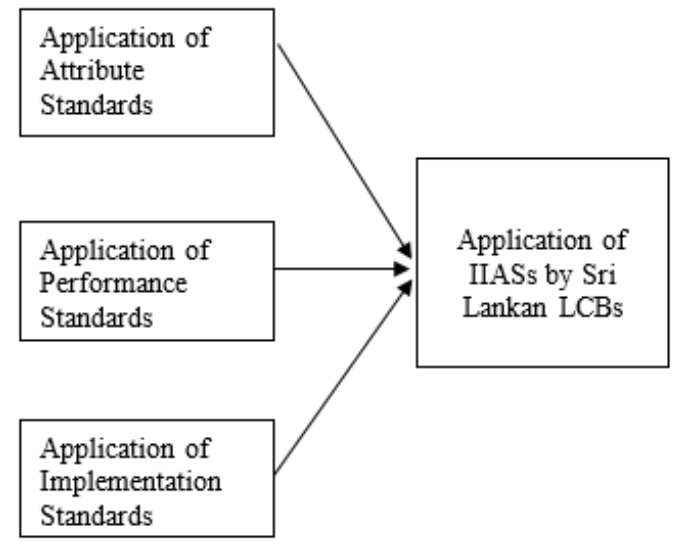

Figure 1. Conceptual Framework

Based on the framework and empirical findings presented by literature review, the following hypotheses were developed to address the research problem.
H1: Application of attribute standards significantly predict the application of IIASs by Sri Lankan LCBs.

$\mathrm{H} 2$ : Application of performance standards significantly predict the application of IIASs by Sri Lankan LCBs.

H3: Application of implementation standards significantly predict the application of IIASs by Sri Lankan LCBs.

\section{METHODS}

A quantitative inquiry of the research questions was performed with the aid of a field survey of the population. Population of the study comprised of all the LCBs in Sri Lanka. As per CBSL (2019) there are 26 LCBs in Sri Lanka. This study is considered a census as it surveyed all 26 LCBs. Out of all $26 \mathrm{LCBs}$, CBSL had identified six large commercial banks as Significantly Important Banks (SIBs). These SIBs consist of two large state banks namely; Bank of Ceylon \& People's Bank and four large private sector banks namely; Commercial Bank, Hatton National Bank, Sampath Bank, and Seylan Bank. All LCBs including these six SIBs were the population of this study. LCBs were the unit of analysis where data was collected from senior audit officials of each bank. The audit function of each bank has been questioned from respondents since each bank has separate unit for audit function. Identical number of representatives, i.e. senior officers from the internal audit departments of each LCB was surveyed. The study succeeded in deriving 179 valid responses from 26 
internal audit departments of all LCBs.

A pre-tested instrument (Shaban, 2013) of 59 items was used with adjustments considering the appropriate of its measurement properties. Response sale of all the instruments was a five point Likert scale in which 1 denoted "Strongly Disagree" and 5 denoted "Strongly Agree". The questionnaire consisted of three sections; A, B, and C. Section A offered the background details of the study including the aims of the study, while section B addressed the demographic factors of the population items. Section $\mathrm{C}$ - possessed the items relating to study variables. As per the conceptual framework, there were four variables namely, the application of three categories of IIASs and the application level of IIASs by LCBs (Figure 1). Three types of standards namely attribute standards, performance standards and implementation standards were identified as independent variables and extent of IIASs application was considered the dependent variable. Summary of the number of items included under each variable has been tabulated in the table 1 .

Table 1. Distribution of Items in the Questionnaire

\begin{tabular}{|l|c|c|}
\hline \multicolumn{1}{|c|}{ Variable } & Section C & $\begin{array}{c}\text { Number of } \\
\text { questions }\end{array}$ \\
\hline $\begin{array}{l}\text { Attribute } \\
\text { Standards }\end{array}$ & Part I & 25 \\
\hline $\begin{array}{l}\text { Performance } \\
\text { Standards }\end{array}$ & Part II & 12 \\
\hline $\begin{array}{l}\text { Implementation } \\
\text { Standards }\end{array}$ & Part III & 10 \\
\hline $\begin{array}{l}\text { Application of } \\
\text { IIASs }\end{array}$ & Part IV & 12 \\
\hline Total & & 59 \\
\hline
\end{tabular}

Table 1 shows the total number of items included under each part of the questionnaire. Sectional distribution of items based on the operationalization of the variables, was shown by the table 2 .

Table 2. Operationalization of the Variables

\begin{tabular}{|c|c|c|c|}
\hline \multirow{2}{*}{\begin{tabular}{|l}
\multicolumn{1}{|c|}{ Variable } \\
Attribute \\
Standards
\end{tabular}} & \multirow{2}{*}{\begin{tabular}{l}
\multicolumn{1}{c}{ Indicator } \\
Purpose, \\
Authority and \\
Responsibility
\end{tabular}} & \multicolumn{2}{|c|}{ Measurement } \\
\hline & & \multirow{15}{*}{ 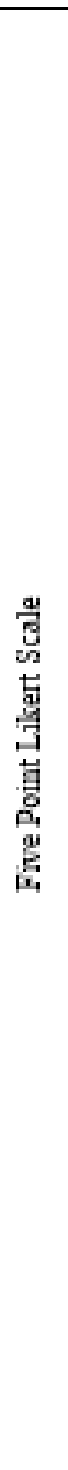 } & 05 \\
\hline & $\begin{array}{l}\text { Independence } \\
\text { and Objectivity }\end{array}$ & & 10 \\
\hline & $\begin{array}{l}\text { Proficiency and } \\
\text { Due } \\
\text { Profeasional } \\
\text { Care }\end{array}$ & & 05 \\
\hline & $\begin{array}{l}\text { Quality } \\
\text { Assurance and } \\
\text { Improvement } \\
\text { Programme }\end{array}$ & & 05 \\
\hline \multirow[t]{4}{*}{$\begin{array}{l}\text { Performance } \\
\text { Standarda }\end{array}$} & $\begin{array}{l}\text { Mannging the } \\
\text { Internal Audit } \\
\text { Activity }\end{array}$ & & 03 \\
\hline & $\begin{array}{l}\text { Nature of work } \\
\text { Performing the } \\
\text { Engagement }\end{array}$ & & 03 \\
\hline & $\begin{array}{l}\text { Monitoring } \\
\text { Progress }\end{array}$ & & 03 \\
\hline & $\begin{array}{l}\text { Communicating } \\
\text { the Acceptance } \\
\text { of Risk }\end{array}$ & & 03 \\
\hline \multirow[t]{4}{*}{$\begin{array}{l}\text { Implementation } \\
\text { Standards }\end{array}$} & $\begin{array}{l}\text { Governance, } \\
\text { Risk and } \\
\text { Compliance } \\
\text { requirements }\end{array}$ & & 03 \\
\hline & Audit Plans & & 05 \\
\hline & $\begin{array}{l}\text { Training for } \\
\text { zudit staff }\end{array}$ & & 01 \\
\hline & Supervision & & 01 \\
\hline \multirow{3}{*}{$\begin{array}{l}\text { Application of } \\
\text { IAAss }\end{array}$} & Knowledge & & 04 \\
\hline & Resources & & 03 \\
\hline & Opinions & & 05 \\
\hline
\end{tabular}

Source: (Shaban, 2013) 
Data analysis was achieved using univariate, bivariate and multivariate techniques. The hypotheses testing was based on the results of multiple regression analysis. A regression model was developed to predict the level of IIASs application based on the application level of each three categories of IIASs.

$\mathrm{Y}=\mathrm{a}+\mathrm{b} 1 \mathrm{X} 1+\mathrm{b} 2 \mathrm{X} 2+\mathrm{b} 3 \mathrm{X} 3$

IIASs $=\mathrm{a}+\mathrm{b} 1 \mathrm{AS}+\mathrm{b} 2 \mathrm{PS}+\mathrm{b} 3 \mathrm{IS}+\mathrm{e}$

where;

IIASs = Application of International Internal Auditing Standards

$\mathrm{AS}=$ Attribute Standards

$\mathrm{PS}=$ Performance Standards

IS $=$ Implementation Standards

$\mathrm{e}=$ Error Term

The Statistical Package for Social Sciences (SPSS), version 23 was used in performing the statistical analyses.

\section{RESULTS}

Statistical data pertaining to demographic factors are presented by the table 3 .

Table 3. Demographic Profile of Respondents

\begin{tabular}{|l|r|r|}
\hline & Frequency & $\begin{array}{c}\text { Percentage } \\
(\%)\end{array}$ \\
\hline \multicolumn{3}{|c|}{ Gender } \\
\hline Male & 138 & 77.1 \\
\hline Female & 41 & 22.9 \\
\hline Total & 179 & 100.0 \\
\hline \multicolumn{3}{|c|}{ Age } \\
\hline $18-25$ & 1 & 67.0 \\
\hline $26-35$ & 120 & 22.9 \\
\hline $36-45$ & 41 & 7.8 \\
\hline $46-55$ & 14 & 1.7 \\
\hline $55-60$ & 3 & 100.0 \\
\hline Total & 179 &
\end{tabular}

\begin{tabular}{|c|c|c|}
\hline \multicolumn{3}{|c|}{ Academic qualifications } \\
\hline Secondary & 72 & 40.2 \\
\hline Degree & 47 & 26.3 \\
\hline Post Graduate & 60 & 33.5 \\
\hline Total & 179 & 100.0 \\
\hline \multicolumn{3}{|c|}{ Professional qualifications } \\
\hline $\begin{array}{l}\text { Certificate or } \\
\text { Diploma in } \\
\text { Banking \& } \\
\text { Finance }\end{array}$ & 45 & 25.1 \\
\hline $\begin{array}{l}\text { Chartered } \\
\text { Accountant }\end{array}$ & 3 & 1.7 \\
\hline $\begin{array}{l}\text { Chartered } \\
\text { Institute of } \\
\text { Management } \\
\text { Accountants }\end{array}$ & 4 & 2.2 \\
\hline $\begin{array}{l}\text { Certified Internal } \\
\text { Auditor }\end{array}$ & 4 & 2.2 \\
\hline $\begin{array}{l}\text { Certificate or } \\
\text { Diploma in } \\
\text { Information } \\
\text { Systems } \\
\text { Security, Control } \\
\text { and Audit } \\
\end{array}$ & 3 & 1.7 \\
\hline Other & 6 & 3.4 \\
\hline Combine & 114 & 63.7 \\
\hline Total & 179 & 100.0 \\
\hline
\end{tabular}

As per table $3,77 \%$ of respondents were male auditors, and $67 \%$ of them were in the age range of 26-35. It implies that the respondents were experienced auditors who are capable of assessing the audit function of the bank. $40 \%$ of the respondents have completed secondary level of their education while $26 \%$ of the respondents have earned degree qualification. $34 \%$ had their post graduate qualifications. In general, $64 \%$ of respondents were having either or combination of these qualifications thus prove to be qualified enough in commenting the application of IIASs. Table 4 presents the results of correlation analysis. 
Table 4. Results of Correlation Analysis

\begin{tabular}{|l|c|c|}
\hline \multicolumn{1}{|c|}{ Variable } & $\begin{array}{c}\text { Application } \\
\text { of IIASs }\end{array}$ & Significance \\
\hline $\begin{array}{l}\text { Attribute } \\
\text { Standards }\end{array}$ & .589 & $.000^{* *}$ \\
\hline $\begin{array}{l}\text { Performance } \\
\text { Standards }\end{array}$ & .199 & $.004^{* *}$ \\
\hline $\begin{array}{l}\text { Implementation } \\
\text { Standards }\end{array}$ & .535 & $.000^{* *}$ \\
\hline
\end{tabular}

** significant at 0.01 level

The table 4 presents the correlation coefficients pertaining to study variables. P c coefficient ) spoke about and direction s. All three components of IIASs share a positive and significant association with the application of IIASs. As such, the results of correlation analysis evident that attribute standards $(r=.589)$ and implementation standards $(\mathrm{r}=.535)$ moderately related with application of IIASs while performance standards show only a weak association with the dependent variable. It implies that application of IIASs is not identical across three components and there is a deficiency of application of performance standards. Next, stepwise multiple regression analysis was performed to explore the individual contribution of three components of IIASs towards the application of IIASs.
Table 5. Model Fit

\begin{tabular}{|c|c|c|c|c|c|}
\hline ఫ్ & i & $\approx$ & 密 & 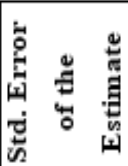 & 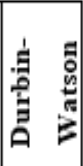 \\
\hline 1 & $.589^{\mathrm{a}}$ & .347 & .343 & .34119 & \\
\hline 2 & $.621^{b}$ & .385 & .378 & .33184 & \\
\hline 3 & $.642^{c}$ & .412 & .402 & .32542 & 1.786 \\
\hline
\end{tabular}

Source: (Survey data)

a. Predictors: (Constant), Attribute

b. Predictors: (Constant), Attribute, Implementation Standards

c. Predictors: (Constant), Attribute, Implementation Standards, Performance Standards

d. Dependent Variable: Application level of IIASs

Table 5 shows the $\mathrm{R} 2$ values of three models. Best model fitting is achieved by the model three. It has $\mathrm{R} 2$ value of $41.2 \%$. The selected model is significant at $99 \%$ confidence level (p $>$.000). Explanatory power of each individual component of IIASs is assessed via beta coefficients of them (table 6). 
Table 6. Regression Analysis Regression Coefficients

\begin{tabular}{|c|c|c|c|c|}
\hline \multicolumn{2}{|r|}{ Model } & 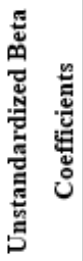 & 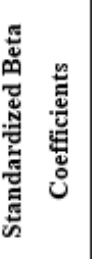 & Sig. \\
\hline \multirow{2}{*}{1} & (Constant) & .678 & & $.030^{*}$ \\
\hline & Attribute & .740 & .589 & $.000 * *$ \\
\hline \multirow{3}{*}{2} & (Constant) & .407 & & .194 \\
\hline & Attribute & .524 & .417 & $.000 * *$ \\
\hline & Implementation & .275 & .261 & $.001^{* *}$ \\
\hline \multirow{4}{*}{3} & (Constant) & .909 & & $.011 *$ \\
\hline & Attribute & .513 & .408 & $.000 * *$ \\
\hline & Implementation & .421 & .400 & $.000 * *$ \\
\hline & Performance & .257 & .211 & $.005 * *$ \\
\hline
\end{tabular}

* Significant at .05 significance level **Significant at .01 significance level

As illustrated by table 6 , model 3 produced significant beta coefficients for all the predictor variables. Accordingly, the regression model can be established as follows.

IIASs $=0.909+0.408 \mathrm{AS}+0.211 \mathrm{PS}+$ $0.400 I S+\mathrm{e}$

where;

IIASs =Application of International Internal Auditing Standards

AS =Attribute Standards

PS =Performance Standards

IS =Implementation Standards

e $\quad=$ Error Term

Here the attribute standards appear affecting the most in deciding the level of IIASs application whereas relatively weaker application of performance and implementation standards are evidenced. Based on the results of regression analysis, hypotheses testing is performed of which the results are summarised by the table 7 .

Table 7. Summary of Hypotheses Testing

\begin{tabular}{|l|l|l|}
\hline \multicolumn{2}{|c|}{ Hypothesis } & Decision \\
\hline $\mathrm{H}_{1}$ & $\begin{array}{l}\text { Application of attribute } \\
\text { standards significantly } \\
\text { predict the application } \\
\text { of IIASs by Sri Lankan } \\
\text { LCBs. }\end{array}$ & Supported \\
\hline $\mathrm{H}_{2}$ & $\begin{array}{l}\text { Application of } \\
\text { performance standards } \\
\text { significantly predict } \\
\text { the application of } \\
\text { IIASs by Sri Lankan } \\
\text { LCBs. }\end{array}$ & Supported \\
\hline $\mathrm{H}_{3}$ & $\begin{array}{l}\text { Application of } \\
\text { implementation } \\
\text { standards significantly } \\
\text { predict the application } \\
\text { of IIASs by Sri Lankan } \\
\text { LCBs. }\end{array}$ & \\
\hline
\end{tabular}

\section{DISCUSSION}

Three components of IIASs namely, attribute standards, performance standards and implementation standards were assumed to be affecting the application of IIASs by Sri Lankan LCBs. These assumptions were statistically supported by the descriptive statistics and multi variate analysis.

Responses for attribute standards had a minimum value of 3.28 , maximum value of 4.84 and mean statistic of 4.0516. It corresponds to the value label "agree" as denoted by the scale of response. Further, the standard deviation was 0.335 . That indicates that there is no significant difference 
among the banks with respect the application of IIASs. There was a positive moderate correlation $(\mathrm{r}=$ 0.589 ) between attribute standards and the application of IIASs. The regression model reflected $41.2 \%$ model fitting out of which $35 \%$ was contributed by the attribute standards. Further, the beta coefficient was positive and was 0.408 at $99 \%$ confidence level. Thus, it is evidenced that the attribute standards become the main contributor of the level of IIASs application by LCBs. The similar findings were presented by Dellai, et al., (2016) in Tunisian context. Further, Marais, et al., (2009), have in the South African context also found attribute standards significantly predicting the application of IIASs. Hence, this finding is considered in line with the existing understanding on the same.

Next, responses for performance standards had a minimum value of 3.00, maximum value of 4.93 and mean statistic of 4.133 which corresponds to "agree" level of the response scale. Further, the standard deviation was 0.345. It implies a relatively even compliance to IIASs among the surveyed LCBs. A positive yet weak correlation $(r=0.199)$ exists between performance standards and application of IIASs. The model was improved by $3 \%$ with the inclusion of performance standards. The predictive power of performance was .211 at the significance level of $1 \%$. This implies that the performance standards, relative to the attribute standards contributes less towards the application of IIASs by Sri Lanka LCBs. It calls for the attention of administrators to craft strategies to enhance the presence of performance standards in the internal auditing function of LCBs. Many researches including, Dellai, et al. (2016), Marais, et al. (2009), Turaev (2017), and Shaban (2013) have identified performance standards as an important determinant of IISAs compliance. Thus, the finding of the present study is considered in line with the existing literature.

Then, the minimum value and maximum values implementation standards responses were 3.00 and 5.00 respectively. The mean statistic was 4.1503 which denoted the "strongly agree" level of the response scale. Moreover, the standard deviation of 0.3992 , showed that no significant variance prevails among the participated LBCs in connection to the application of implementation standards. A positive and moderate association $(\mathrm{r}=0.535)$ was reported between implementation standards and application of IIASs. The overall model improved by $4 \%$ of with the addition of implementation standards. Standardised beta coefficient of 0.400 suggested the explanatory power of implementation standards. This implies the significant role played by the implementation standards in affecting the application of IIASs by LCBs. Identical results were reported by other researchers including, Metlib \& Turki (2017), Marais, et al., (2009), Dellai, et al., (2016), and Shaban (2013). Hence, the findings appear compatible with the present body of knowledge. These results had been proven in different territories as well. In Uzbekistan it had been identified by that attribute and performance standards needs further improvements 
(Turaev, 2017). Shaban (2013) concluded that the Jordanian telecommunication industry greatly applies attributes standards and implementation standards while no performance standards are not applied (Shaban, 2013). Thius, the findings of the present study appear to apply for the entire banking industry in the region and in particular to the banking industry of the South Asian region.

\section{CONCLUSION}

The main objective of the study was to find out the application of IIASs by Sri Lankan LCBs in their internal audit function. Three main components of IIASs namely, attribute standards, performance standards and implementation standards were tested against their impact towards the extent of IIASs application. Hypotheses were established in the light of available literature which were supported by the data analysis. Findings aided in concluding that the LCBs apply IIASs in their internal audit function at a moderate level. Further, it was observed that all three components of IIASs are applied at varying degrees by LCBs. Among them, attribute and implementation standards were at moderate level while weak application of performance standards was noted. Accordingly, it can be concluded that LCBs apply IIASs in their internal audit function and among the IIASs, attribute standards and implementation standards are applied moderately while performance standards are applied at a weak level. To the best knowledge of the researchers, there had been no any research work carried out in the Sri Lankan context with regard to application level of IIASs. Hence, the contribution of this research is utmost important to the "auditing" profession and to the banking industry as a whole. This research has contributed to fill the existing contextual gap in the internal auditing in the form of IIASs application. The research findings evident that LCBs apply IIASs at varying degrees. However, there is no legal requirement for Sri Lankan banks to apply IIASs. Therefore, LCBs may not fully devoted to ensure the compliance towards these international standards as a mandatary requirement. However, the company's ordinance no 07 of 2017, has mandate all the registered companies to follow SLAuSs and to state the same by the statutory auditor of the LCB in their annual reports as well. But for IIASs, there is no such binding requirement. Yet, application of SLAuSs automatically led application of IIASs to a greater extent as the SLAuSs are based on IIASs.

However, IIASs have greater acceptance in the global context relative to the country-specific SLAuSs. As per CBSL, LCBs are the single largest player in the economy and they determine the health of the financial sector. Hence, it is undoubtful that the health and the openness of these LCBs to vulnerabilities should be carefully controlled and evaluated. for which it is essential to apply IIASs. As such, it would be beneficial for banks to apply IIASs to assess the potential vulnerabilities. Similarly, it would be essential in facing the open competition in the global financial market. 
The limitation of the study includes that it was geographically confined to Sri Lanka. Hence, generalization of the results in to global context may be somewhat questionable. The conclusions applied only to banking industry but not to other industries. Further, study focused only the commercial banks while specialized banks, development banks and other financial institutions operating in Sri Lanka were not considered. Additionally, sample didn't include foreign LCBs operating in Sri Lanka. Future researchers are invited in breaking through these limitations. As such, future researches can be directed towards considering different geographical areas as well as different industries.

Internal auditing is an important function and as well a reputed profession in Sri Lanka. But it is yet to receive the attention of scholars. The finding of the present study are expected to lay the seeds for policy reforms to promote the application of all three components of IIASs and as well to guide a new stream of financial researches in Sri Lanka.

\section{REFERENCES}

Anon., 2019. Cambridge Dictionary. [Online] Available at: https://dictionary.cambridge.org/ dictionary/english/audit?q=Audit [Accessed 0204 2019].

Anon., 2019. English Oxford Living Dictionary. [Online] Available at: https://en.oxforddictionaries.com/ definition/audit [Accessed 0204 2019].
Anon., 2019. Macmillan Dictionary. [Online] Available at: https://www.macmillandictionary .com/dictionary/british/audit_1 [Accessed 0204 2019].

Asian Development Bank, 2002. Diagnostic Study of Accounting and Auditing Practices in Sri Lanka. Diagnostic Study of Accounting and Auditing Practices.

Bandara, G. R. E. L., 1988. Internal Audit. Colombo 7: Municipal press.

Basu, S. K., 2007. Auditing Principles and Techniques. India: Pearson Education.

CA Sri Lanka, 2018. Sri Lanka Auditing Standards (SLAuSs). [Online] Available at: https://www.casrilanka.com [Accessed 0204 2019].

Calema, P. and Michael, L., 2004. Risk-based capital requirements for mortgage loans. Journal of Banking \& Finance, pp. 647-672.

CBSL, 2018. Banking Sector. [Online] Available at: https://www.cbsl.gov.lk/en/financ ial-system/financial-systemstability/banking-sector [Accessed 0204 2019].

CBSL, 2019. www.cbsl.gov.lk. [Online] Available at: https://www.cbsl.gov.lk/en/about/ about-the-bank/bank-history [Accessed 0204 2019]. 
CBSL, 2019. www.cbsl.gov.lk. [Online] Available at: https://www.cbsl.gov.lk/en/financ ial-system/financial-systemstability/overview [Accessed 02 04 2019].

Chambers, A. D., Selim, J. M. and Vinten, G., 1987. Internal Auditing. London: Bath Press.

COSO, 2013. Internal ControlIntegrated Frame work, Darham: American Institute for Certified Public Accountants.

COSO, 2019. www.coso.org. [Online] Available at https://www.coso.org/Pages/defa ult.aspx [Accessed 1004 2019].

Dellai, H. and Omri, M. A. B., 2016. Factors Affecting the Internal Audit Effectiveness in Tunisian Organizations. Research Journal of Finance and Accounting, 7(16).

Edirisuriya, P., 2007. Effects of Financial Sector Reforms in Sri Lanka: Evidence from the Banking Sector. Asia Pacific Journal of Finance and Banking REsearch, 1.

Gamage, C. T., Lock, K. L. \& Fernando, A. A. J., 2014. International Journal of Scientific Research and Innovative Technology, 1.

Gunathilaka, A. G. C., 2012. Audit Expectation Gap in Sri Lanka:The Role of Policy Makers. International Journal of Multidisciplinary Research, 2(10), p. 2.
Hemachandra, W. M., 2010. Competition and Financial Sector Development in Sri Lanka. Sri Lanka Journal of Advanced Social Studies, 2.

IFAC， 2018. 2018 Handbook of International Quality Control, Auditing, Review, Other Assurance, and Related Services Pronouncements. [Online] Available at: http://www.ifac.org [Accessed 0204 2019].

IIA, 2015. International Professional Practice Framework (IPPF), USA: Chartered Institute of Internal Auditors.

Jain, D. P., 1996. Auditing. s.l.:Konark Publishers.

Jayaweera, R. A., 1989. Auditing. Colombo 10: S Godage and Brothers.

Kagermann, H., Kinney, W., Kuting, K. and Weber, C. P., 2008. Internal Audit handbook. Texas: Springer.

Knechel, W. R. and Saltario, S. E., 2017. Auditing Assurance and Risk. In: Auditing Assurance and Risk. New York: Routledge, p. 12.

Kumar, R. and Sharma , V., 2011. Auditing Principles and Practice. New Delhi: PHI Learning .

Liyanarachchi, G. A., 2009. Accounting in ancient Sri Lanka. Accounting History.

Makgatho, K. E., 2016. Effectiveness of internal control mechanisms in 
monitoring financial resources at the Gauteng Department of Education. p. 3.

Marais, M. et al., 2009. Usage of Internal Auditing Standards and Internal auditing Activities in South Africa and all Respondents. Managerial Auditing Journal.

Metlib, A. S. A. and Turki , A. A., 2017. A Theoretical Discussion of Internal Audit Effectiveness in Kuwaiti Industrial SMEs. International Journal of Academic Research in Accounting, Finance and Management Sciences, 7(1).

Millichamp, H. A., 2002. Auditing. London: ELST.

Moor, D. S., Notz, W. I. \& Flinger, M. A., 2013. The basic practice of statistics. New York: W.H.Freeman and Company.

Prem, W. S. Y., Sarath, L. U. J. and Siriwardhane, P., 2017. The professionalisation of auditing in less developed countries:The case of Sri Lanka. Emerald insight.

Ramamoorthi, S., 2003. Internal Auditing:History, Evolution and Prospects, USA: The Institute of Internal Auditors Research Foundation.

S Calem, P. and Michael, L., 2004. Risk-based capital requirements for mortgage loans. Journal of Banking \& Finance, pp. 647-672.

Salder, E., Fourie, H. and Marais, M., 2008. Internal auditor's compliance with the IIA
Standards: a worldwide perspective. Meditari Accountancy Research.

Sarbanes-Oxley-101, 2019. www.sarbanes-oxley-101.com/.

[Online] Available at: https://www.sarbanes-oxley101.com/ [Accessed 1704 2019].

Shaban, O. S., 2013. British Journal of Applied Science and Technology.

The Institute of Internal Auditos Research Foundation, 2012. Sawer's Guide for Internal Auditors. Florida: The Institute of Internal Auditos Research Foundation.

Turaev, A., 2017. Adoption of International Internal Audit Standards in Uzbekistan:. Research Journal of Finance and Accounting, 07(02).

U.S. Embassies abroad, 2019. http://export.gov/usoffices.

[Online] Available at: https://www.export.gov/article?id =Sri-Lanka-Banking-Systems [Accessed 1704 2019].

Zengin, S. and Yu ksel, S., 2016. Affecting factor of liquidity Risks: An examination. Istanbul Ticaret University Social, 15(29), pp. 7795. 